\title{
Identification and characterization of genome-wide resistance gene analogs (RGAs) of durian (Durio zibethinus L.)
}

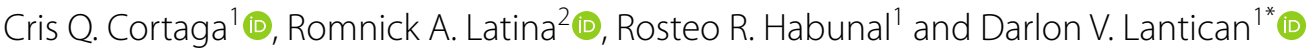

\begin{abstract}
Background: Durian (Durio zibethinus L.) is a tropical fruit crop which is popular in Southeast Asia but recently gaining popularity in other parts of the world. In this study, we analyzed the resistance gene analogs (RGAs) of durian through mining of the currently available reference genome of its 'Musang King' cultivar (PRJNA400310).

Results: A total of 2586 RGAs were identified in the durian genome consisting of 47 nucleotide binding site proteins (NBS), 158 NBS-leucine rich repeat proteins (NL), 400 coiled-coil NBS-LRR (CNL), 72 toll/interleukin-1 receptor NBS-LRR (TNL), 54 coiled-coil NBS (CN), 10 toll/interleukin-1 receptor NBS (TN), 19 toll/interleukin-1 receptor with unknown domain (TX), 246 receptor-like proteins (RLP), 1,377 receptor-like kinases (RLK), 185 TM-CC, and 18 other NBS-containing proteins with other domains. These RGAs were functionally annotated and characterized via gene ontology (GO) analysis. Among the RGAs with the highest copies in durian genome include the putative disease resistance RPP13like protein 1, disease resistance protein At4g27190, disease resistance protein RPS6, Probable disease resistance protein At4g27220, and putative disease resistance protein RGA3, while 35 RGAs were found to be novel. Phylogenetic analyses revealed that the genome-wide RGAs were broadly clustered into four major clades based on their domain classification.
\end{abstract}

Conclusion: To our knowledge, this is the most comprehensive analysis of durian RGAs which provides a valuable resource for genetic, agronomic, and other biological research of this important tropical fruit crop.

Keywords: Durian, Genome-wide, Resistance gene analogs (RGAs), Plant defense, Bioinformatics

\section{Introduction}

Plants sense insect pests and pathogen invasion via pathogen recognition receptors (PRRs) in the cell, whereas attacker-specific effectors are identified via a gene-forgene interaction through resistance $(\mathrm{R})$ proteins [1-3]. The PRRs and $R$ genes are referred to as resistance gene analogs (RGAs) which share conserved domains and motifs [4]. They are in charge of intracellular signaling and turning on plant defense genes. PRRs are made up of membrane-associated RLKs and RLPs. RLKs have

\footnotetext{
*Correspondence: dvlantican@up.edu.ph

${ }^{1}$ Institute of Plant Breeding (IPB), College of Agriculture, University

of the Philippines Los Baños, 4031 College, Laguna, Philippines

Full list of author information is available at the end of the article
}

an extracellular sensing domain, such as a leucine-rich repeat (LRR) domain or a lysin motif (LysM) domain, a transmembrane (TM) domain, and an intracellular kinase domain, whereas RLPs have a similar structure except for the absence of an intracellular kinase domain [5]. The $\mathrm{R}$ proteins are intracellular effector-recognition receptors and contain certain domains/motifs such as serine/ threonine kinases, nucleotide binding sites (NBS), LRRs, TMs, leucine-zipper, coiled-coil (CC), and toll/interleukin-1 receptor (TIR) $[4,6,7]$. Among these, majority of $R$ proteins belong to NBS-LRR class. Meanwhile, the subgroups of NBS-encoding proteins are designated as NBS, CNL, TNL, CN, TN, NL, TX, and other NBS protein that shows chimeric domain/motif architecture. 
The advent of genomics technologies facilitated the development of DNA markers tagging economic traits, characterization of diverse protein families, and discovery of novel biological insights into numerous species at the genome-wide scale [8-11]. As a useful tool for resistance breeding, the RGAs have been widely studied to obtain a deeper insight on the underlying molecular defenses of the plant. Since RGAs in plants have conserved structural properties, bioinformatics investigations of next-generation sequencing (NGS) data may be used to undertake comprehensive RGA prediction [12-15]. Several studies have exemplified the utility of these RGAs as a rich source of functional markers not just for tagging pest resistant loci for many crops [16] for plant molecular breeding [17] but also for genetic structure and diversity analyses [18].

Durian (Durio zibethinus L.) is a tropical fruit crop grown in Southeast Asia known for its distinct taste and aroma. Also hailed as the "king of fruits", it has started to gain popularity in the USA and other parts of the world leading to an increasing economic market value. Several studies have also proven its high nutritional and nutraceutical potential [19]. However, the primary restrictions to obtaining optimal durian production include diseases such as root rot, stem rot, and fruit rot, as well as insect pests [20]. Recently, the whole genome of durian (c.v. Musang King) with a haploid size of $738 \mathrm{Mb}$ had been published [21]. The availability of its genomic reference has paved the way to more in-depth research opportunities for durian, such as those related to understanding insect and pathogen resistance. Through mining of the currently released durian genome, the genome-wide RGAs of durian were identified and characterized in this paper. To the best of our knowledge, this work covers the most comprehensive identification, characterization, and evolutionary investigation of durian RGAs.

\section{Materials and methods Identification and classification of durian RGAs}

The predicted gene models from the whole genome of durian were accessed from Teh et al. (2017) (NCBI BioProject PRJNA400310) for RGA analysis. Using the automated RGA prediction pipeline RGAugury [4], the genome-wide RGA of durian belonging to membrane associated RLK and RLP families, and NBS and TM-CC containing proteins were identified in the gene models from the annotated durian genome. Using an $e$-value cut-off of $1 \mathrm{e}-5$, the input protein sequences were filtered using a BLASTp search against the RGAdb database of the RGAugury software package.

\section{Characterization and annotation of durian RGAs}

The RGAs of durian were functionally annotated using the BLAST2GO package [22]. The homology of the protein sequences of each predicted RGAs was determined through BLASTp analysis (with $e$-value of $1 \mathrm{e}-5$ ) using the UniProtKB/SwissProt protein database. The mapped BLAST hits were then merged to InterProScan [23] search output to produce the gene ontology (GO) annotations, such as the molecular function (MF), biological processes (BP), and cellular component (CC), which were designated to each RGA protein identified from the whole genome of durian.

\section{Evolutionary analysis of durian RGAs}

Multiple sequence alignment was done using the FASTA amino acid sequences of the genome-wide RGAs of durian as input using the CLUSTALW program [24] with the following parameters: Gap Opening Penalty: 10; Gap Extension Penalty: 0.2. The maximum likelihood statistical approach in IQ-TREE [25] was used to construct phylogenetic of the aligned protein sequences, with the best-fit substitution model selected using ModelFinder [26] according to the Bayesian information criterion (BIC). The phylogenetic tree was generated with 1000 iterations of ultrafast bootstrapping [27] using a generic matrix (JTT) with empirical amino acid frequencies $(+\mathrm{F})$ and discrete Gamma $(+\mathrm{G} 4)$ rate heterogeneity across sites. FigTree (v1.4.4) [28] was used to display and preprocess the phylogenetic tree that had been constructed.

\section{Results and discussion} Identification of RGAs

RGAugury [4], an efficient integrative bioinformatics pipeline for predicting RGAs in plants using NGS data, was used to identify RGAs from the retrieved gene models of the whole genome of Musa King durian variety [21]. Durian RGAs are made up of 47 NBS, 400 CNL, 72 TNL, 54 CN, 10 TN, 158 NL, 19 TX, 246 RLP, 1377 RLK, 185 TM-CC, and 18 other NBS-containing proteins with other domains, totaling 2586 RGAs (Table 1; Additional file 1). When the genome-wide RGAs of durian were compared to the predicted RGAs reported from other plant species [13], it was revealed that it has the most RGAs (2586), followed by peach (2005), orange (1806), mango (1775), rice (1537), cacao (1171), Arabidopsis (979), corn (935), tomato (922), banana (769), and finally, papaya (402). (Table 1). The RGA content and characteristics of a plant have been linked to resistance [29], and the high number of RGAs in durian may imply substantial innate plant resistance. 


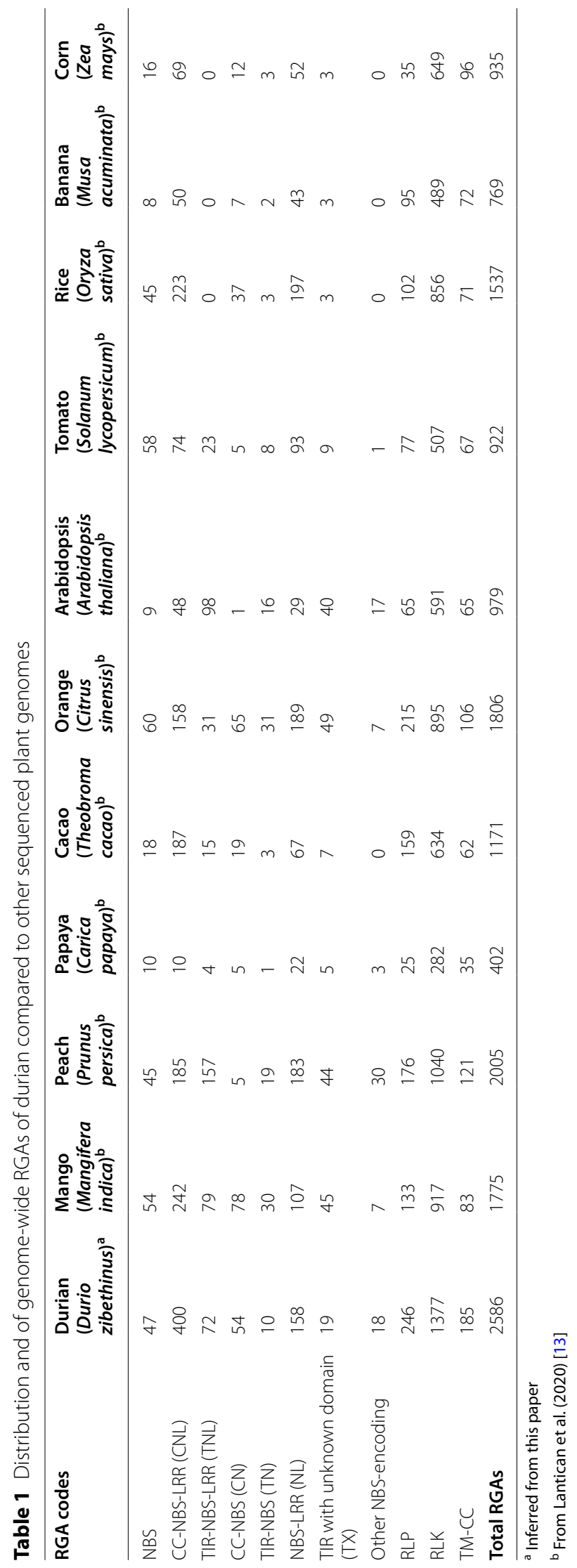


Among the RGAs investigated, the RLK was the most common group comprising the majority of RGAs found in the analyzed plant genomes (Table 1). In durian, 1377 RLK genes were identified which accounted for half (or 53.2\%) of the predicted RGAs followed by 778 NBS-encoding genes (30.1\%) (Table 1, Fig. 1). The NBS-encoding genes are the frequent targets for $R$ gene analysis and, thus, are the best-known and wellidentified family of RGAs. In the pineapple genome, 177 NBS-encoding genes were identified [14] while 352 NBS-encoding genes were identified in the sunflower genome [7]. As a dicot species, durian contains all NBS-encoding proteins (NBS, CNL, TNL, CN, TN, NL, TX, and other NBS-encoding proteins), unlike monocots (e.g., rice, banana, and corn), which typically lack the TNL protein (Table 1) [30]. TNL genes are thought to have been lost from the monocot lineage following the divergence of dicots and monocots [14]. Eighteen putative RGAs were designated as "other" NBSencoding proteins (Table 1) because they had chimeric domain/ motif architecture, i.e., unexpected domain combination of TIR and CC domains [4]. In terms of RLPs and TM-CC, the durian genome contains 246 and 185 genes, respectively or $9.5 \%$ and $7.2 \%$ of the total durian RGAs, respectively (Table 1, Fig. 1).

\section{GO functional annotation of RGAs}

GO analysis was used to determine the associated molecular functions, biological processes, and cellular localizations of the durian genome-wide RGAs. As most RGAs are extra- and intracellular binding receptors that modulate cellular defense signaling via a cascade of kinase activities [31], their molecular functions are primarily associated with protein/nucleotide binding and kinase activity (Fig. 2a; Additional file 2a). On the other hand, the biological processes of RGAs are extremely diverse, resulting in a wider array of GO terms. The RGAs are primarily involved in protein autophosphorylation during cellular signal transductions, defense/resistance/immune responses to various stresses caused by biotic (e.g., insects and diseases) and abiotic (e.g., water deprivation, salt stress, UV stress) factors, and in various plant growth and development processes (from embryonic to floral/pollen development) (Fig. 2b; Additional file 2b).

Several RGAs are also involved in hormone-mediated signaling pathways and systemic acquired resistance which include the phytohormones abscisic acid, jasmonic acid, auxin, salicylic acid, gibberellic acid, ethylene, cytokinin, and brassinosteroids (Additional file 2b). Crosstalk between these plant hormones is critical for modulating defense signaling and activating systemic resistance against pathogens and insect pests [32]. As expected, RGAs are predominantly located in the cell's membranes, plasmodesma, cytoplasm/cytosol, and nucleus (Fig. 2c; Additional file 2c), as these are important recognition sites for pathogen/insect attack and effector proteins. The RGAs in these cellular components operate to transform extracellular stimuli into intracellular responses for defense activation.

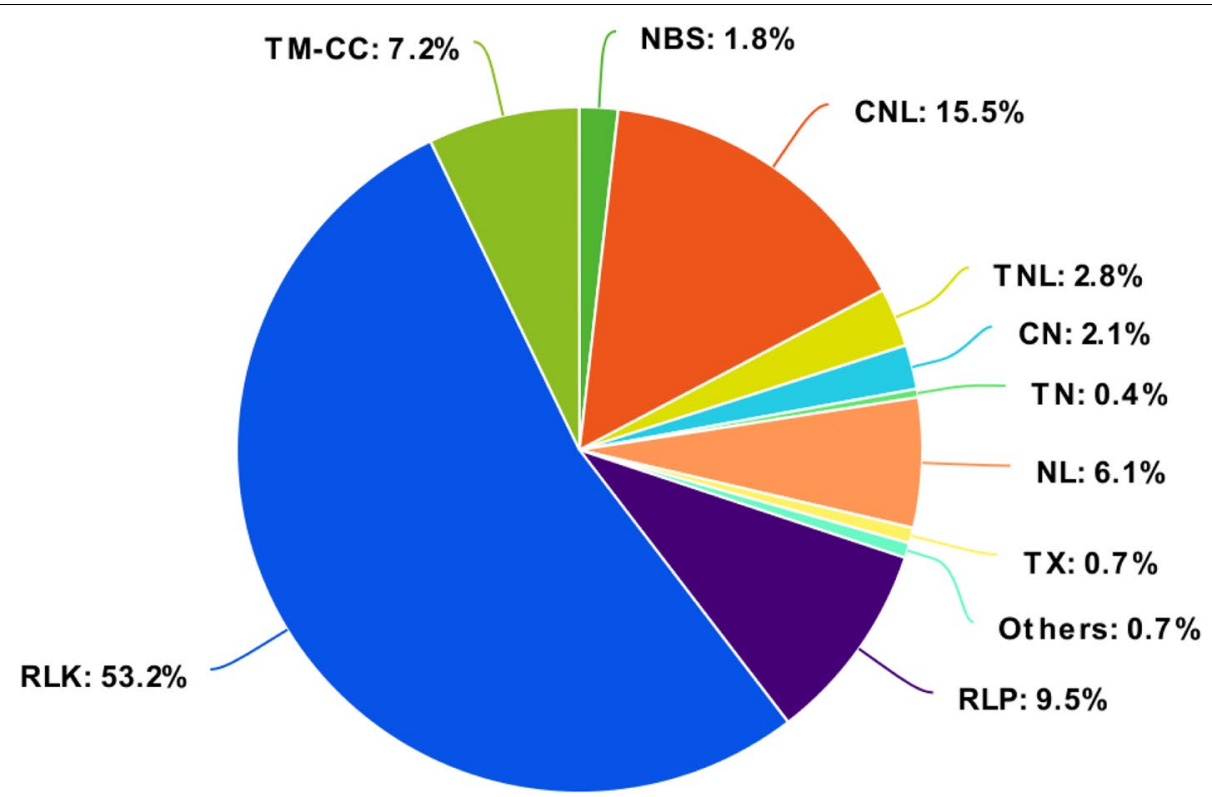

Fig. 1 Percentage and distribution of the classifications based on conserved domains and motifs of genome-wide RGAs of durian 


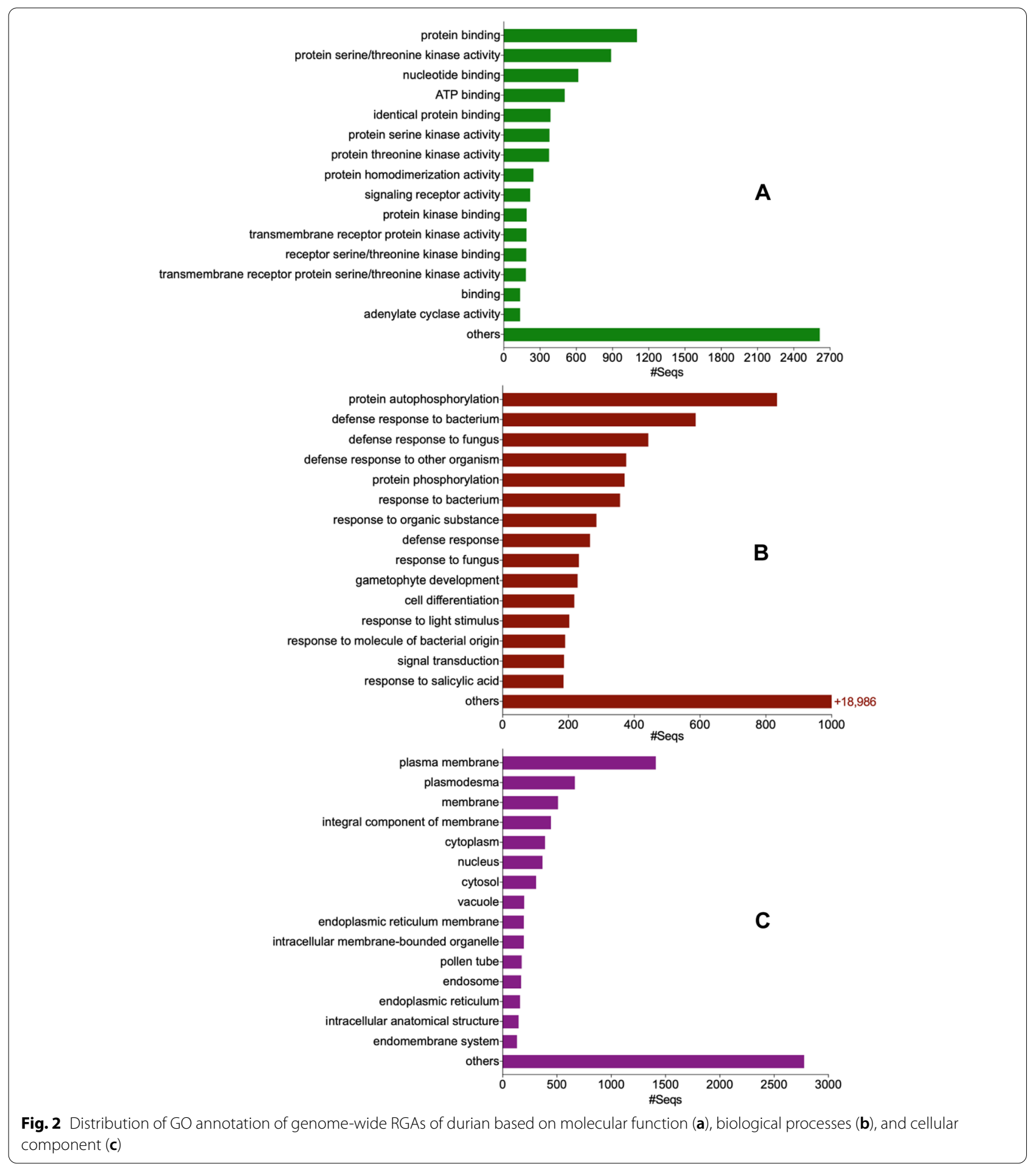

\section{Durian resistance $(\mathrm{R}) /$ defense proteins}

The durian genome-wide RGAs exhibited similarity to a wide range of well-known R/defense proteins (Table 2; Additional file 3). Among these predicted RGA proteins are LRK10L/Lr10 resistance proteins against leaf rust caused by Puccinia triticina [33]; RPP resistance proteins against downy mildew caused by Peronospora parasitica [34]; Resistance proteins R1-A and RGA/RGA-blb protect against the catastrophic late blight disease brought by Phytophthora infestans [35]; RRS1 resistance proteins 
Table 2 Durian RGAs with homology to well-known resistance proteins

\begin{tabular}{|c|c|c|c|}
\hline Recommended name & Alternative name & Domain & No. of copies \\
\hline Putative disease resistance RPP13-like protein 1 & & $C N, C N L, N B S, N L$ & 207 \\
\hline Disease resistance protein At4g27190 & & CN, CNL, NBS, NL, OTHER & 135 \\
\hline Disease resistance protein RPS6 & Resistance to Pseudomonas syringae 6 & NL, OTHER, TN, TNL, TX & 94 \\
\hline Probable disease resistance protein At4g27220 & & CNL, NBS, NL, OTHER & 66 \\
\hline Putative disease resistance protein $\mathrm{RGA3}$ & Blight resistance protein B149; RGA1-blb & $C N, C N L, N B S, N L, R L P$ & 53 \\
\hline Putative disease resistance protein RGA1 & RGA3-blb & $C N, C N L, N B S, N L$ & 37 \\
\hline Disease resistance protein RPM1 & Resistance to Pseudomonas syringae protein 3 & $\mathrm{CNL}, \mathrm{NL}$ & 16 \\
\hline Probable disease resistance protein At1g15890 & & CN, NBS & 15 \\
\hline Disease resistance protein RPS4 & Resistance to Pseudomonas syringae 4 & $C N L, N L, T N L, R L P$ & 13 \\
\hline Putative disease resistance protein RGA4 & RGA4-blb & $\mathrm{CN}, \mathrm{CNL}, \mathrm{NBS}, \mathrm{NL}$ & 13 \\
\hline Disease resistance protein SUMM2 & $\begin{array}{l}\text { Disease resistance protein At1g12280; Protein SUP- } \\
\text { PRESSOR OF MKK1 MKK2 } 2\end{array}$ & $\mathrm{CN}, \mathrm{CNL}$ & 12 \\
\hline Probable disease resistance protein At5g63020 & $\mathrm{pNd} 11$ & $\mathrm{CN}, \mathrm{CNL}$ & 12 \\
\hline Disease resistance protein RGA2 & Blight resistance protein RPI; RGA2-blb & $\mathrm{CN}, \mathrm{NL}$ & 9 \\
\hline Disease resistance protein RPS5 & $\begin{array}{l}\text { Resistance to Pseudomonas syringae protein } 5 ; \\
\text { pNd3/pNd10 }\end{array}$ & $\mathrm{CN}, \mathrm{CNL}, \mathrm{NL}$ & 9 \\
\hline Putative disease resistance protein At1g50180 & & $\mathrm{CNL}, \mathrm{NL}$ & 9 \\
\hline Probable disease resistance protein At1g61190 & & CN, NBS & 7 \\
\hline $\begin{array}{l}\text { LEAF RUST } 10 \text { DISEASE-RESISTANCE LOCUS RECEP- } \\
\text { TOR-LIKE PROTEIN KINASE-like } 1.2\end{array}$ & $\begin{array}{l}\text { Probable receptor-like serine/threonine-protein } \\
\text { kinase LRK10L-1.2 }\end{array}$ & RLK & 6 \\
\hline Disease resistance protein RRS1 & $\begin{array}{l}\text { Disease resistance protein } \mathrm{RCH} 2 \text {; Probable WRKY } \\
\text { transcription factor } 52 \text {; Resistance to Colletotrichum } \\
\text { higginsianum } 2 \text { protein; Resistance to Ralstonia } \\
\text { solanacearum } 1 \text { protein }\end{array}$ & NBS, TN & 5 \\
\hline $\begin{array}{l}\text { LEAF RUST } 10 \text { DISEASE-RESISTANCE LOCUS RECEP- } \\
\text { TOR-LIKE PROTEIN KINASE-like } 1.3\end{array}$ & $\begin{array}{l}\text { Probable receptor-like serine/threonine-protein } \\
\text { kinase LRK10L-1.3 }\end{array}$ & RLK & 5 \\
\hline Probable disease resistance protein At5g66900 & & $\mathrm{CNL}, \mathrm{NL}$ & 5 \\
\hline Putative disease resistance protein At4g 10780 & & $\mathrm{CN}, \mathrm{CNL}, \mathrm{NL}$ & 5 \\
\hline Rust resistance kinase Lr10 & $\begin{array}{l}\text { Probable receptor-like serine/threonine-protein } \\
\text { kinase LRK10 }\end{array}$ & RLK & 5 \\
\hline Disease resistance RPP13-like protein 4 & $\begin{array}{l}\text { Disease resistance protein ZAR1; Protein HOPZ-ACTI- } \\
\text { VATED RESISTANCE 1; AtZAR1 }\end{array}$ & $\mathrm{CNL}, \mathrm{NL}$ & 4 \\
\hline $\begin{array}{l}\text { LEAF RUST } 10 \text { DISEASE-RESISTANCE LOCUS RECEP- } \\
\text { TOR-LIKE PROTEIN KINASE-like } 2.1\end{array}$ & $\begin{array}{l}\text { Probable receptor-like serine/threonine-protein } \\
\text { kinase LRK10L-2.1 }\end{array}$ & RLK & 4 \\
\hline Putative disease resistance protein At3g 14460 & & $\mathrm{CNL}$ & 4 \\
\hline Disease resistance protein RPS2 & Resistance to Pseudomonas syringae protein 2 & CNL, NBS & 3 \\
\hline Probable disease resistance protein At1g58390 & & $\mathrm{CNL}, \mathrm{NL}$ & 3 \\
\hline Probable disease resistance protein At1g61300 & & CN, NBS & 3 \\
\hline Putative disease resistance protein At1g63350 & & $\mathrm{CN}, \mathrm{NL}$ & 3 \\
\hline Disease resistance protein RFL1 & RPS5-like protein 1; pNd13/pNd14 & $\mathrm{CN}$ & 2 \\
\hline Disease resistance protein RPP8 & Resistance to Peronospora parasitica protein 8 & $\mathrm{NL}$ & 2 \\
\hline Disease resistance RPP8-like protein 3 & & $\mathrm{NL}$ & 2 \\
\hline $\begin{array}{l}\text { LEAF RUST } 10 \text { DISEASE-RESISTANCE LOCUS RECEP- } \\
\text { TOR-LIKE PROTEIN KINASE-like } 1.5\end{array}$ & $\begin{array}{l}\text { Probable receptor-like serine/threonine-protein } \\
\text { kinase LRK10L-1.5 }\end{array}$ & RLK & 2 \\
\hline $\begin{array}{l}\text { LRR receptor-like serine/threonine-protein kinase } \\
\text { ERECTA }\end{array}$ & $\begin{array}{l}\text { Protein QUANTITATIVE RESISTANCE TO PLECTO- } \\
\text { SPHAERELLA 1; Protein QUANTITATIVE RESISTANCE TO } \\
\text { RALSTONIA SOLANACEARUM 1; Protein TRANSPIRA- } \\
\text { TION EFFICIENCY } 1\end{array}$ & RLK & 2 \\
\hline Probable disease resistance protein At4g33300 & & $\mathrm{NL}$ & 2 \\
\hline Probable disease resistance RPP8-like protein 4 & & $\mathrm{NL}$ & 2 \\
\hline
\end{tabular}


Table 2 (continued)

\begin{tabular}{|c|c|c|c|}
\hline Recommended name & Alternative name & Domain & No. of copies \\
\hline Disease resistance protein RRS1 & $\begin{array}{l}\text { Disease resistance protein RCH2; Disease resistance } \\
\text { protein SLH1; Probable WRKY transcription factor 52; } \\
\text { Protein RPS4-homolog; Protein SENSITIVE TO LOW } \\
\text { HUMIDITY 1; Resistance to Colletotrichum higgin- } \\
\text { sianum } 2 \text { protein; Resistance to Ralstonia solan- } \\
\text { acearum } 1 \text { protein; WRKY DNA-binding protein } 52\end{array}$ & NBS & 1 \\
\hline Disease resistance protein UNI & Protein UNI & $\mathrm{CN}$ & 1 \\
\hline Late blight resistance protein R1-A; Protein R1 & & NBS & 1 \\
\hline $\begin{array}{l}\text { LEAF RUST } 10 \text { DISEASE-RESISTANCE LOCUS RECEP- } \\
\text { TOR-LIKE PROTEIN KINASE-like } 1.1\end{array}$ & $\begin{array}{l}\text { Probable receptor-like serine/threonine-protein } \\
\text { kinase LRK10L-1.1 }\end{array}$ & RLK & 1 \\
\hline $\begin{array}{l}\text { LEAF RUST } 10 \text { DISEASE-RESISTANCE LOCUS RECEP- } \\
\text { TOR-LIKE PROTEIN KINASE-like } 2.5\end{array}$ & $\begin{array}{l}\text { Probable receptor-like serine/threonine-protein } \\
\text { kinase LRK10L-2.5 }\end{array}$ & RLK & 1 \\
\hline $\begin{array}{l}\text { LEAF RUST } 10 \text { DISEASE-RESISTANCE LOCUS RECEP- } \\
\text { TOR-LIKE PROTEIN KINASE-like } 2.8\end{array}$ & $\begin{array}{l}\text { Probable receptor-like serine/threonine-protein } \\
\text { kinase LRK10L-2.8 }\end{array}$ & RLK & 1 \\
\hline Probable disease resistance protein At1g52660 & & NBS & 1 \\
\hline Probable disease resistance protein At5g45440 & & NBS & 1 \\
\hline Probable disease resistance protein At5g47260 & & NBS & 1 \\
\hline Probable disease resistance RPP8-like protein 2 & & $\mathrm{NL}$ & 1 \\
\hline ToMV resistance protein Tm-2(2) & $\begin{array}{l}\text { Disease resistance protein } \mathrm{Tm}-2(2) \text {; ToMV resistance } \\
\text { protein } T m-2 a\end{array}$ & $\mathrm{CNL}$ & 1 \\
\hline
\end{tabular}

Table 3 Durian RGAs with homology to proteins in UniProtKB/SwissProt database with "response to insect" GO annotation

\begin{tabular}{|c|c|c|c|}
\hline Recommended name & Alternative name & Domain & No. of copies \\
\hline $\begin{array}{l}\text { Probable LRR receptor-like serine/threonine-protein kinase } \\
\text { At1g56130 }\end{array}$ & & RLK & 15 \\
\hline $\begin{array}{l}\text { Probable LRR receptor-like serine/threonine-protein kinase } \\
\text { At1g07650 }\end{array}$ & & RLK & 15 \\
\hline $\begin{array}{l}\text { Probable leucine-rich repeat receptor-like serine/threonine- } \\
\text { protein kinase At3g } 14840\end{array}$ & & RLK & 13 \\
\hline $\begin{array}{l}\text { Probable LRR receptor-like serine/threonine-protein kinase } \\
\text { RFK1 }\end{array}$ & Receptor-like kinase in flowers 1 & RLK & 10 \\
\hline $\begin{array}{l}\text { Probable LRR receptor-like serine/threonine-protein kinase } \\
\text { At1g53430 }\end{array}$ & & RLK & 2 \\
\hline $\begin{array}{l}\text { Probable LRR receptor-like serine/threonine-protein kinase } \\
\text { At1g53440 }\end{array}$ & & RLK & 2 \\
\hline Probable serine/threonine-protein kinase At1g01540 & & RLK & 2 \\
\hline $\begin{array}{l}\text { Probable LRR receptor-like serine/threonine-protein kinase } \\
\text { RKF3 }\end{array}$ & Receptor-like kinase in flowers 3 & RLK & 2 \\
\hline C-type lectin receptor-like tyrosine-protein kinase At1g52310 & & RLK & 2 \\
\hline $\begin{array}{l}\text { Cysteine-rich receptor-like protein kinase 3; Cysteine-rich } \\
\text { RLK3 }\end{array}$ & & RLK & 1 \\
\hline Calmodulin-binding receptor kinase CaMRLK; & $\begin{array}{l}\text { Calmodulin-binding receptor-like kinase; AtCaMRLK; Protein } \\
\text { MATERNAL EFFECT EMBRYO ARREST } 62\end{array}$ & RLK & 1 \\
\hline $\begin{array}{l}\text { Probable LRR receptor-like serine/threonine-protein kinase } \\
\text { At1g56140 }\end{array}$ & & RLK & 1 \\
\hline MDIS1-interacting receptor like kinase 2; AtMIK2 & $\begin{array}{l}\text { Probable LRR receptor-like serine/threonine-protein kinase } \\
\text { At } 4 \text { g08850 }\end{array}$ & RLK & 1 \\
\hline $\begin{array}{l}\text { LysM domain receptor-like kinase 4; LysM-containing } \\
\text { receptor-like kinase } 4\end{array}$ & & RLK & 1 \\
\hline Probable receptor-like protein kinase At1g11050 & & RLK & 1 \\
\hline
\end{tabular}




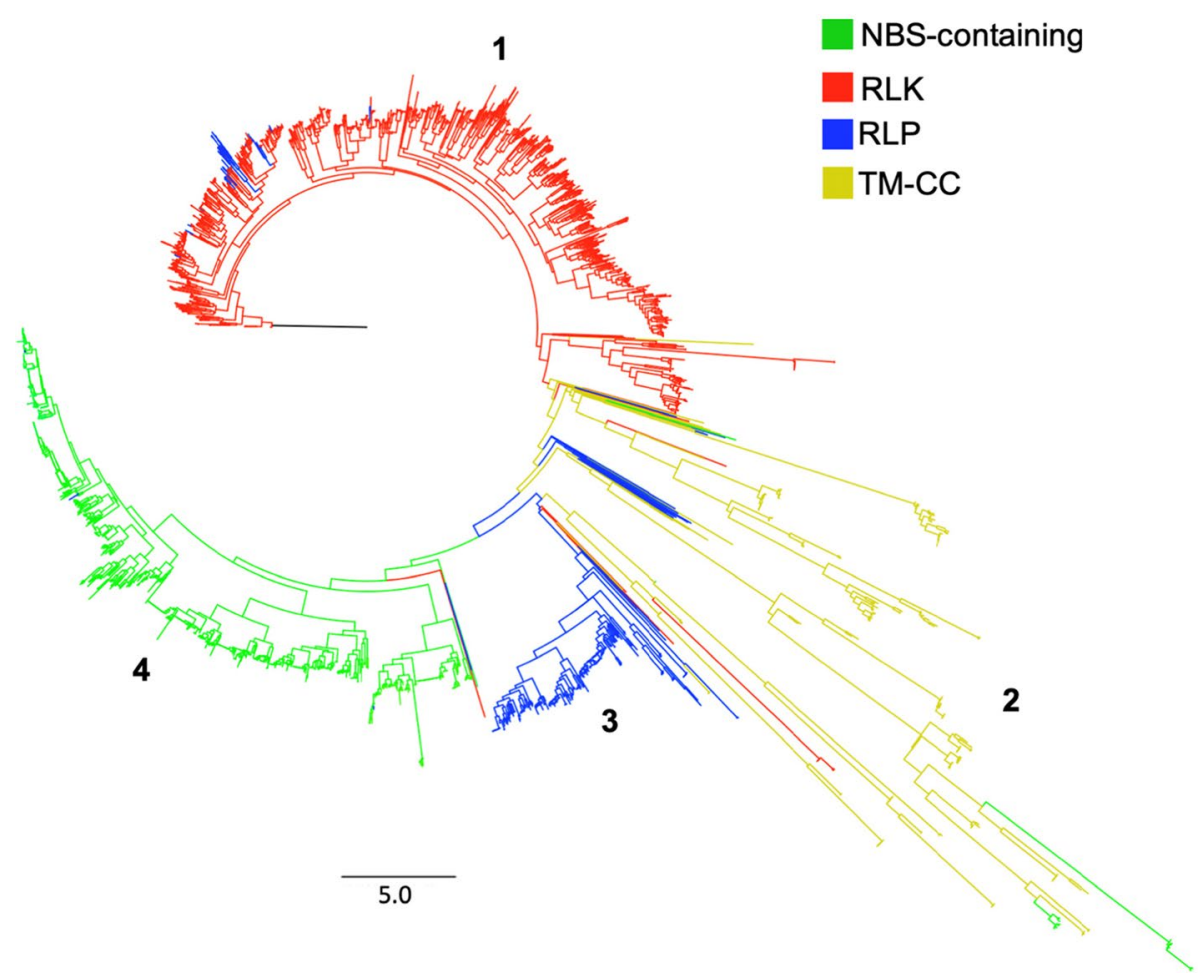

Fig. 3 Maximum likelihood phylogenetic tree constructed from the sequence alignment of genome-wide RGAs of durian

(probable WRKY transcription factor) against Colletotrichum higginsianum and Ralstonia solanacearum [36]; ToMV resistance protein $\mathrm{Tm}-2$ (2) against certain tobamoviruses including, tomato mosaic virus (ToMV) and tobacco mosaic virus (TMV) [37]; RPS and RPM1 resistance proteins against the biotrophic pathogen Pseudomonas syringae [38]; and ERECTA protein for quantitative resistance to Ralstonia solanacearum bacterial wilt and the necrotrophic fungus Plectosphaerella [39]. In plants, this protein is also involved in the regulation of efficient transpiration [40].

The durian RGAs also shared homology with the SUMM2 protein (SUPPRESSOR OF mkk1 mkk2 2), which is triggered when the pathogen effector HopAI1 disrupts the MEKK1-MKK1/MKK2-MPK4 cascade in the basal defense response [41, 42]. The disease resistance protein UNI, which is implicated in disease resistance by exhibiting constitutive expression of pathogenesis-related genes via the salicylic acid (SA) signaling pathway, was also found $[43,44]$. It is also vital to the development of shoot architecture via the cytokinin signaling system $[43,44]$. Homology to the Disease resistance protein RFL1, a RPS5-like protein 1 , was also identified in durian RGA (Table 2). Other $\mathrm{R}$ proteins present in durian revealed similarity to a number of putative disease resistance proteins from
Arabidopsis thaliana (At) that have yet to be extensively investigated (Table 2).

Among these well-known resistance proteins, the five highest copies in the durian genome include the putative disease resistance RPP13-like protein 1 (207 copies), disease resistance protein At4g27190 (135 copies), disease resistance protein RPS6 (94 copies), Probable disease resistance protein At4g27220 (66 copies), and putative disease resistance protein RGA3 (53 copies) (Table 2). Further filtering of genome-wide RGAs linked with the GO term "insect response" (GO:0009625) revealed 15 RGAs that may play key roles in insect defense pathways (Table 3). Notably, all of these RGAs were shown to have RLK domains, as was also observed in mango [13], where insect responsive RGAs possess RLK/RLP domains. On the other hand, 35 RGAs were revealed to be novel, or their biological functions have not yet been investigated in durian (Additional file 3).

\section{Evolutionary relationships of RGAs}

To investigate the evolutionary relationships and diversity of durian RGAs, a maximum likelihood phylogenetic tree (Fig. 3) was built using the best-fit model determined based on BIC (Additional file 4). The RGAs were mostly clustered based on their conserved domains and motifs, indicating four major 
clades (corresponding to four major RGA families) with subclades from other RGA domains (Fig 3 ). Clade 1 is mostly made up of RLKs, with subclades that include RLPs and TM-CC. Clade 2 is dominated by TM-CC, with several subclades from all other RGA domains. Unlike in the TM-CC proteins derived from genomic sequences which form a distinct clade, the TM-CC proteins derived from transcriptomic sequences can form widespread subclades in the phylogenetic tree as observed in mango [13] and sugarcane [29]. Clade 3 is mostly made up of RLPs with subclades from other RGA domains, particularly TM-CC, which created a large, nested subclade. Clade 4 is made up of NBS-containing proteins (NBS, CNL, TNL, CN, TN, NL, TX, and other NBS proteins), with minor subclades including RLP and RLK.

One of the selective forces that have been ascribed to the diversity and evolutionary pattern of RGAs in plants is the co-evolutionary "arms race" between the host plant and associated pests and diseases to overcome each other $[45,46]$. The diversity of RGAs have also been correlated to climatic conditions (e.g., temperature, rainfall, humidity) that promote disease growth and spread [47]. The prevalence of wholegenome duplications and genomic reorganizations in ancient periods has also been linked to the expansion of RGA families and the emergence of novel gene functions in plants [48]. These are some of the factors that may have impacted the evolutionary structure of RGAs of durian, which is mostly cultivated in tropical environments.

\section{Conclusion}

In this study, we successfully identified and characterized the genome-wide RGAs of durian through mining of the currently available reference genome from Musang King cultivar. A considerable number of genome-wide RGAs (2586) were identified in durian which were broadly classified into four major families based on their conserved structural features, i.e., 778 NBS-encoding proteins, 1377 RLKs, 246 RLPs, and 185 TM-CC proteins. The RGAs were functionally annotated to provide a better understanding of their associated MFs, BPs, and CCs, as well as insights into the overall functional response of durian to insect pests and diseases. Furthermore, the investigation of the evolutionary relationships and diversity of RGAs serves as an invaluable reference in the design of framework for genetic improvement of durian. With this, the thorough RGA analysis performed in this work offers a vital resource for genetic, agronomic, and other biological studies on this important tropical fruit crop.

\section{Abbreviations}

RGA: Resistance gene analog; PRRs: Pathogen recognition receptors; $R$ : Resistance; NBS: Nucleotide binding site proteins; NL: NBS-leucine rich repeat proteins; CNL: Coiled-coil NBS-LRR; TNL: Toll/interleukin-1 receptor NBS-LRR; CN: Coiled-coil NBS; TN: Toll/interleukin-1 receptor NBS; TX: Toll/interleukin-1 receptor with unknown domain; RLP : Receptor-like proteins; RLK: Receptorlike kinases; TM:Transmembrane; CC: Coiled coil; LRR: Leucine-rich repeat; TIR: Toll/interleukin-1 receptor; LysM: Lysin motif; NGS: Next-generation sequencing; GO: Gene ontology; MF: Molecular function; BP: Biological processes; CC: Cellular component.

\section{Supplementary Information}

The online version contains supplementary material available at https://doi. org/10.1186/s43141-022-00313-8.

Additional file 1. FASTA protein sequences of Resistance Gene Analogs identified in durian.

Additional file 2. Direct GO counts of Molecular Function (MF), Biological Process (BP) and Cellular Component (CC) of durian genome-wide RGAs.

Additional file 3. BLAST2GO annotation results of identified RGA proteins.

Additional file 4. Bayesian Information Criterion (BIC) scores for the selection of best substitution model for phylogenetic tree construction.

\section{Acknowledgements}

This study was supported by the University of the Philippines Los Baños (UPLB) under the Institute of Plant Breeding core-funded project "Genomewide analysis of RGAs and development of RGA-linked DNA markers in Philippine Important Crops".

\section{Authors' contributions}

CQC conducted the conceptualization, data curation and interpretation, and writing the original draft. RAL_-review and editing, conceptualization, and analysis. $\mathrm{RRH}$ - conceptualization and initial analysis. DVL-conceptualization, review and editing, funding acquisition, and project administration. All authors have read and approved the final manuscript for publication.

\section{Funding}

University of the Philippines Los Baños (UPLB)-Institute of Plant Breeding (IPB) Core Fund.

\section{Availability of data and materials}

The datasets supporting the conclusions of this article are included within the article (and its additional files).

\section{Declarations}

Ethics approval and consent to participate

Not applicable.

\section{Consent for publication \\ Not applicable.}

\section{Competing interests}

The authors declare that they have no competing interests.

\section{Author details}

${ }^{1}$ Institute of Plant Breeding (IPB), College of Agriculture, University of the Philippines Los Baños, 4031 College, Laguna, Philippines. ${ }^{2}$ Institute of Weed Science, Entomology, and Plant Pathology (IWEP), College of Agriculture and Food Science, University of the Philippines Los Baños, 4031 College, Laguna, Philippines.

Received: 14 October 2021 Accepted: 4 February 2022

Published online: 14 February 2022 


\section{References}

1. Thompson JN, Burdon JJ (1992) Gene-for-gene coevolution between plants and parasites. Nature 360:121-125. https://doi.org/10.1038/36012 $1 \mathrm{a} 0$

2. Acevedo FE, Rivera-Vega $L$, Chung SH et al (2015) Cues from chewing insects - the intersection of DAMPs, HAMPs, MAMPs and effectors. Curr Opin Plant Biol. 26:80-86. https://doi.org/10.1016/j.pbi.2015.05.029

3. Choi HW, Klessig DF (2016) DAMPs, MAMPs, and NAMPs in plant innate immunity. BMC Plant Biol 16. https://doi.org/10.1186/s12870-016-0921-2

4. Li P, Quan X, Jia G et al (2016) RGAugury: a pipeline for genome-wide prediction of resistance gene analogs (RGAs) in plants. BMC Genomics 17. https://doi.org/10.1186/s12864-016-3197-x

5. Tör M, Lotze MT, Holton N (2009) Receptor-mediated signalling in plants: molecular patterns and programmes. J Exp Bot 60. https://doi.org/10. 1093/jxb/erp233

6. Gururani MA, Venkatesh J, Upadhyaya CP et al (2012) Plant disease resistance genes: current status and future directions. Physiol Mol Plant Pathol 78:51-65. https://doi.org/10.1016/j.pmpp.2012.01.002

7. Neupane S, Andersen EJ, Neupane A, Nepal MP (2018) Genome-wide identification of NBS-encoding resistance genes in sunflower (Helianthus annuus L.). Genes 9. https://doi.org/10.3390/genes9080384

8. Goodwin S, McPherson JD, McCombie WR (2016) Coming of age: ten years of next-generation sequencing technologies. Nat. Rev. Genet. 17:333-351. https://doi.org/10.1038/nrg.2016.49

9. Kanchan M, Ramkumar TR, Himani SJK (2021) Genome-wide characterization and expression profiling of the phospholipase C (PLC) gene family in three orchids of economic importance. J Genet Eng Biotechnol 19. https://doi.org/10.1186/s43141-021-00217-z

10. Sahay A, Piprodhe A, Pise M (2020) In silico analysis and homology modeling of strictosidine synthase involved in alkaloid biosynthesis in Catharanthus roseus. J Genet Eng Biotechnol 18. https://doi.org/10.1186/ s43141-020-00049-3

11. Saidi A, Hajibarat Z (2021) Genome wide identification of StKNOX gene family and characterization of their expression in Solanum tuberosum. Biocatal Agric Biotechnol 37. https://doi.org/10.1016/j.bcab.2021.102160

12. Lantican DV, Strickler SR, Canama AO et al (2019) De novo genome sequence assembly of dwarf coconut (Cocos nucifera L. 'Catigan Green Dwarf') provides insights into genomic variation between coconut types and related palm species. G3 Genes. Genomes, Genet 9:2377-2393. https://doi.org/10.1534/g3.119.400215

13. Lantican DV, Cortaga CQ, Manohar ANC et al (2020) Resistance gene analogs of mango: Insights on molecular defenses and evolutionary dynamics. Philipp J Sci 149:915-934

14. Zhang X, Liang P, Ming R (2016) Genome-wide identification and characterization of nucleotide-binding site (NBS) resistance genes in pineapple. Trop Plant Biol 9:187-199. https://doi.org/10.1007/s12042-016-9178-z

15. Karthika R, Prasath D, Anandaraj M (2019) Transcriptome-wide identification and characterization of resistant gene analogs (RGAs) of ginger (Zingiber officinale Rosc.) and mango ginger (Curcuma amada Roxb.) under stress induced by pathogen. Sci Hortic (Amsterdam) 248:81-88. https:// doi.org/10.1016/j.scienta.2019.01.003

16. Hasan N, Choudhary S, Naaz N, et al (2021) Recent advancements in molecular marker-assisted selection and applications in plant breeding programmes. J. Genet. Eng. Biotechnol. 19. https://doi.org/10.1186/ s43141-021-00231-1

17. Amiteye S (2021) Basic concepts and methodologies of DNA marker systems in plant molecular breeding. Heliyon 7. https://doi.org/10.1016/j. heliyon.2021.e08093

18. Ren J, Yu Y, Gao F et al (2013) Application of resistance gene analog markers to analyses of genetic structure and diversity in rice. Genome 56:377-387. https://doi.org/10.1139/gen-2012-0142

19. Aziz NAA, Jalil AMM (2019) Bioactive compounds, nutritional value, and potential health benefits of indigenous durian (Durio zibethinus Murr.): a review. Foods 8. https://doi.org/10.3390/foods8030096

20. Visutsak P (2021) Ontology-based semantic retrieval for durian pests and diseases control system. Int J Mach Learn Comput 11:92-97 https://doi. org/10.18178/ijmlc.2021.11.1.1019

21. Teh BT, Lim K, Yong CH et al (2017) The draft genome of tropical fruit durian (Durio zibethinus). Nat Genet 49:1633-1641. https://doi.org/10. 1038/ng.3972
22. Conesa A, Götz S, García-Gómez JM et al (2005) Blast2GO: a universal tool for annotation, visualization and analysis in functional genomics research. Bioinformatics 21:3674-3676. https://doi.org/10.1093/bioinformatics/ bti610

23. Zdobnov EM, Apweiler R (2001) InterProScan - an integration platform for the signature-recognition methods in InterPro. Bioinformatics 17:847-848. https://doi.org/10.1093/bioinformatics/17.9.847

24. Thompson JD, Higgins DG, Gibson TJ (1994) CLUSTAL W: Improving the sensitivity of progressive multiple sequence alignment through sequence weighting, position-specific gap penalties and weight matrix choice. Nucleic Acids Res 22:4673-4680. https://doi.org/10.1093/nar/22 22.4673

25. Nguyen LT, Schmidt HA, Von Haeseler A, Minh BQ (2015) IQ-TREE: a fast and effective stochastic algorithm for estimating maximum-likelihood phylogenies. Mol Biol Evol 32:268-274. https://doi.org/10.1093/molbev/ msu300

26. Kalyaanamoorthy S, Minh BQ, Wong TKF et al (2017) ModelFinder: fast model selection for accurate phylogenetic estimates. Nat Methods 14:587-589. https://doi.org/10.1038/nmeth.4285

27. Hoang DT, Chernomor O, Von Haeseler A et al (2018) UFBoot2: Improving the ultrafast bootstrap approximation. Mol Biol Evol 35:518-522. https:// doi.org/10.1093/molbev/msx281

28. Rambaut A (2018) FigTree v1.4.4. Retrieved 07 Feb 2020 from http://tree. bio.ed.ac.uk/software/figtree/

29. Rody HVS, Bombardelli RGH, Creste $S$ et al (2019) Genome survey of resistance gene analogs in sugarcane: genomic features and differential expression of the innate immune system from a smut-resistant genotype. BMC Genomics 20. https://doi.org/10.1186/s12864-019-6207-y

30. Tarr DEK, Alexander HM (2009) TIR-NBS-LRR genes are rare in monocots: Evidence from diverse monocot orders. BMC Res Notes 2. https://doi.org/ 10.1186/1756-0500-2-197

31. Cristina M, Petersen M, Mundy J (2010) Mitogen-activated protein kinase signaling in plants. Annu Rev Plant Biol 61:621-649. https://doi.org/10. 1146/annurev-arplant-042809-112252

32. Pieterse CMJ, Van der Does D, Zamioudis C et al (2012) Hormonal modulation of plant immunity. Annu Rev Cell Dev Biol 28:489-521. https://doi. org/10.1146/annurev-cellbio-092910-154055

33. Shiu SH, Bleecker AB (2003) Expansion of the receptor-like kinase/Pelle gene family and receptor-like proteins in Arabidopsis. Plant Physiol 132:530-543. https://doi.org/10.1104/pp.103.021964

34. Bittner-Eddy PD, Crute IR, Holub EB, Beynon JL (2000) RPP13 is a simple locus in Arabidopsis thaliana for alleles that specify downy mildew resistance to different avirulence determinants in Peronospora parasitica. Plant J 21:177-188. https://doi.org/10.1046/j.1365-313X.2000.00664.x

35. Lokossou AA, Rietman H, Wang M et al (2010) Diversity, distribution, and evolution of Solanum bulbocastanum late blight resistance genes. Mol Plant-Microbe Interact 23:1206-1216. https://doi.org/10.1094/ MPMI-23-9-1206

36. Narusaka M, Shirasu K, Noutoshi Y, et al (2009) RRS1 and RPS4 provide a dual Resistance-gene system against fungal and bacterial pathogens. Plant J 60:218-226. https://doi.org/10.1111/j.1365-313X.2009.03949.x

37. Lanfermeijer FC, Dijkhuis J, Sturre MJG et al (2003) Cloning and characterization of the durable tomato mosaic virus resistance gene Tm-22 from Lycopersicon esculentum. Plant Mol Biol 52:1037-1049. https://doi.org/10. 1023/A:1025434519282

38. Kim SH, II KS, Saha D et al (2009) Resistance to the Pseudomonas syringae effector hopA1 is governed by the TIR-NBS-LRR Protein rps6 and is enhanced by mutations in srfr1. Plant Physiol 150:1723-1732. https://doi. org/10.1104/pp.109.139238

39. Sanchez-Rodriguez C, Estévez JM, Llorente F et al (2009) The ERECTA receptor-like kinase regulates cell wall-mediated resistance to pathogens in Arabidopsis thaliana. Mol Plant-Microbe Interact 22:953-963. https:// doi.org/10.1094/MPMI-22-8-0953

40. Masle J, Gilmore SR, Farquhar GD (2005) The ERECTA gene regulates plant transpiration efficiency in Arabidopsis. Nature 436:866-870. https://doi. org/10.1038/nature03835

41. Zhang Z, Wu Y, Gao M et al (2012) Disruption of PAMP-induced MAP kinase cascade by a Pseudomonas syringae effector activates plant immunity mediated by the NB-LRR protein SUMM2. Cell Host Microbe 11:253-263. https://doi.org/10.1016/j.chom.2012.01.015 
42. Kong Q, Qu N, Gao M et al (2012) The MEKK1-MKK1/MKK2-MPK4 kinase cascade negatively regulates immunity mediated by a mitogen-activated protein kinase kinase kinase in Arabidopsis. Plant Cell 24:2225-2236. https://doi.org/10.1105/tpc.112.097253

43. Igari K, Endo S, Hibara Kl et al (2008) Constitutive activation of a CC-NBLRR protein alters morphogenesis through the cytokinin pathway in Arabidopsis. Plant J 55:14-27. https://doi.org/10.1111/j.1365-313X.2008. 03466.x

44. Ogawa T, Mori A, Igari Ket al (2016) Efficient in planta detection and dissection of de novo mutation events in the Arabidopsis thaliana disease resistance gene UNI. Plant Cell Physiol 57:1123-1132. https://doi.org/10. 1093/pcp/pcw060

45. Anderson JP, Gleason CA, Foley RC et al (2010) Plants versus pathogens: an evolutionary arms race. Funct Plant Biol 37: 499-512. https://doi.org/ 10.1071/FP09304

46. Edger PP, Heidel-Fischer HM, Bekaert M et al (2015) The butterfly plant arms-race escalated by gene and genome duplications. Proc Natl Acad Sci 112:8362-8366. https://doi.org/10.1073/pnas.1503926112

47. Sela H, Cheng J, Jun Y et al (2009) Divergent diversity patterns of NBS and LRR domains of resistance gene analogs in wild emmer wheat populations. Genome 52:557-565. https://doi.org/10.1139/G09-030

48. Michelmore RW, Meyers BC (1998) Clusters of resistance genes in plants evolve by divergent selection and a birth-and-death process. Genome Res 8:1113-1130. https://doi.org/10.1101/gr.8.11.1113

\section{Publisher's Note}

Springer Nature remains neutral with regard to jurisdictional claims in published maps and institutional affiliations.

\section{Submit your manuscript to a SpringerOpen ${ }^{\circ}$ journal and benefit from:}

- Convenient online submission

- Rigorous peer review

- Open access: articles freely available online

- High visibility within the field

- Retaining the copyright to your article

Submit your next manuscript at $\gg$ springeropen.com 